\title{
The advantage of using independent subdivisions during archaeological excavations for the study of small vertebrate remains
}

Intérêts de l'utilisation des décapages lors des fouilles archéologiques pour l'étude des restes de petits vertébrés

\section{Aurélien Royer}

\section{OpenEdition}

\section{Journals}

\section{Electronic version}

URL: http://journals.openedition.org/paleo/3017

DOI: 10.4000/paleo.3017

ISSN: 2101-0420

\section{Publisher}

SAMRA

\section{Printed version}

Date of publication: 28 December 2014

Number of pages: $277-286$

ISSN: $1145-3370$

Electronic reference

Aurélien Royer, "The advantage of using independent subdivisions during archaeological excavations for the study of small vertebrate remains », PALEO [Online], 25 | 2014, Online since 28 July 2015, connection on 07 July 2020. URL : http://journals.openedition.org/paleo/3017 ; DOI : https://doi.org/ 10.4000/paleo.3017

This text was automatically generated on 7 July 2020. 


\title{
The advantage of using independent subdivisions during archaeological excavations for the study of small vertebrate remains
}

\author{
Intérêts de l'utilisation des décapages lors des fouilles archéologiques pour \\ l'étude des restes de petits vertébrés
}

Aurélien Royer

I wish to thank Odile Romain for giving me access to the collection from Olha 1 (PyrénéesAtlantiques) at the Musée de l'Homme, Bruno Maureille and Alan Mann for the Pradelles collection (Charente), as well as Mathieu Langlais for Peyrazet (Lot). I also thank Véronique Laroulandie, Luca Sitzia, Emmanuelle Stoetzel and Jean-Pierre Texier for their precious comments which improved this text.

\section{1 - Introduction}

1 Prehistorians are regularly called upon to reevaluate series from the early excavations of sites now considered as references. These reevaluations are generally carried out when a "discrepancy" is observed between former interpretations and current knowledge. The latter evolves continuously as a result of new discoveries, leading to the formulation of new issues and the use of new methods, or as a result of the development of new analytic paradigms. The main aim of the renewed study of collections is thus to revise and update the archaeological and stratigraphic interpretations of the site based on material derived from early excavations.

2 The history of a prehistoric site is a subjective reconstruction based on the interpretation of the sedimentary and geomorphological context, as well as on the different unearthed archaeological and paleontological remains. Among these remains, faunal remains in particular allow us to address the exploitation of the animal 
environment by Man, to establish biostratigaphies and to reconstruct past environments. For their part, small vertebrate remains present two specific traits:

1) they are regularly present in sites with the required conditions for bone fossilization, and 2) they can either be separate from human occupation remains or associated with them. Nonetheless, when they are associated with artefacts, their accumulation rarely results from anthropogenic activities (Chaline 1977). Thus, unlike the large fauna, these assemblages are only exceptionally biased by human predation activities. On the other hand, they can be influenced by the agent(s) responsible for their accumulation (e.g., Mayhew 1977; Andrews 1990; Stahl 1996). In addition, these small vertebrates, mainly represented by rodents (e.g. Chaline 1977), occupy many different ecological zones. On account of their small size, wide diversity and rather sedentary behaviour, they reflect a local environment. Given the fact that they react rapidly to environmental variations, small vertebrates provide privileged evidence of environmental changes near sites (e.g. Le Louarn and Quéré 2003; Hernández Fernández 2006; Auffray, Renaud, Claude 2009). In this way, environmental reconstructions were developed from the beginning of the $20^{\text {th }}$ century onwards (e.g. Harlé 1906; Bouchud 1952; Simard 1966; Chaline1972; Jeannet 1978; Marquet 1993; Cuenca-Bescós et al. 2009; Jeannet 2010; López-García et al. 2010; Royer et al. 2013). In most cases, they refer to the archaeological layers defined during excavations.

In this article, two questions are broached: 1) what consequences would the recording by layer of data relative to the small vertebrates have on future interpretations and reevaluations? 2) Are the archaeostratigraphic subdivisions sufficiently relevant for the study of small vertebrate palaeo-associations? Based on the analysis of three small mammal collections from sites excavated at different periods (the sites of Olha I in the Pyrénées-Atlantiques, Pradelles in Charente and Peyrazet in the Lot), this work shows that it is preferable to record and collect small vertebrate remains by successive subdivisions (or spits). This method is easy to implement and leads to the conservation of neutral and independent information that can be directly compared to data from the other archaeological remains.

\section{2 - Limits and implications of the archaeological layers}

An archaeological layer is defined as a soil unit made up of deposits left by Man or containing the remains of his activities (Leroi-Gourhan 1988). The identification of such a layer is based on all the different remains found at the site.

The archaeological layer is independent of the geological layer, defined as "a sedimentary unit that accumulated in constant physical conditions" (Reineck and Singh 1975, p. 82). This definition of an archaeological layer is theoretical. In practice, the delimitation of such levels is difficult and involves an interpretation of the site and the material used to identify these layers (Bordes, Rigaud, Sonneville-Bordes (de) 1972). Moreover, archaeological layers are often only defined on the basis of initial field observations, and are thus based on geological, rather than archaeological criteria (i.e.; characteristics of the deposits containing artefacts, such as texture or colour). Therefore the definition of archaeological layers is often questionable and doubts often arise as to the reality of such entities. As a result, it is not easy to interpret remains for which the only recorded spatial information is the archaeological layer from which they derive (Villa 2004). 
7 From the 1930s, Méroc developed a rating system for objects using orthonormal Cartesian markers (Laplace-Jauretche and Méroc 1954), which was swiftly adopted from the middle of the $20^{\text {th }}$ century onwards (e.g. Leroi- Gourhan 1950; Bordes and Bourgon 1951; Sonneville- Bordes (de) and Mortureux 1955; Vaufrey 1956). With this system, it is possible to record the exact position of remains in a site and thus obtain neutral information. It has become essential in current excavation methods and makes it possible to continue the analysis of archaeological complexes once excavation operations are finished. The collections from early excavations using this system can thus be reevaluated. Nonetheless, this system was only developed for large objects that can be identified at the excavation.

8 Sieving was practiced from the end of the $19^{\text {th }}$ century onwards in order to retrieve objects that went unnoticed at the excavation. However, it was only from the second half of the $20^{\text {th }}$ century that sieving became systematic and was linked to the site grid (e.g. Lumley (de) 1969, 1972). In order to recover as much information as possible, Laplace-Jauretche (1971) suggested subdividing the whole site into 5 or $10 \mathrm{~cm}$ slices, respectively called half size and full size. According to him, these subdivisions are " subordinated to the stratigraphy defined by a set of geological and cultural characteristics" (1971, p.228). Nonetheless, such a definition is contrary to the rules of stratigraphy (Hedberg 1979). These subdivisions must not depend on litho- and archaeostratigraphic sequences so that they remain independent and can then be correlated with them. Today, they are known as "subdivisions" or "spits", according to the definition in the dictionary of prehistory (Leroi-Gourhan 1988). They represent the volume of a hexahedron with a surface of $1 / 9,1 / 4$ or 1 square metre and a thickness varying between 1 and $10 \mathrm{~cm}$, following the excavation protocols used. This recording mode thus leads to the accumulation of information for pieces recorded directly at the excavation, as well as for those retrieved during sieving and sorting, so that each object can be situated in the site according to Cartesian markers.

\section{3 - How can we interpret an early collection of small vertebrates?}

9 Let us take the example of the collection of small vertebrates from Olha I (PyrénéesAtlantiques). In 1936, Passemard published the results of his excavations of the Olha 1 site, excavated between 1916 and 1919. He described a sequence nearly 7 metres thick, made up of six stratigraphic complexes (Passemard 1936). The study of the small faunal remains showed the presence of four rodent and two insectivore species. These were from a single layer located in an intermediary position between layers FS and FM. The revision of this collection showed that all the bone remains (mandibles, humeri, femurs) are whole, suggesting the selective collection of material. This observation led to questions as to the consequences of this collection and on the representativeness of the material. Moreover, three additional rodent species were identified (tab. 1). As, exceptionally, the current distribution areas of these species overlap, it is reasonable to ask if their association is "real", or if it stems from an excavation artifact linked to the collection of material.

10 Finally, the revision of such a series allows for 1) a more accurate identification of the remains 2) the reconsideration of the integrity of the series and the identification of any possible taphonomic biases. However, the absence of information concerning the 
localization of remains, independently of their ascribed layer, is not conducive to environmental or biostratigraphic reinterpretations.

Table 1 - Presence of small vertebrates from the "inter FM-FS" level of Olha 1 (PyrénéesAtlantiques) identified by Passemard (1936), as well as the minimal number of individuals for small vertebrates identified during reevaluation.

\begin{tabular}{|c|c|c|c|}
\hline & & $\begin{array}{c}\text { Espèces décrites } \\
\text { par Passemard } \\
(1936)\end{array}$ & $\begin{array}{l}\text { Espèces } \\
\text { identifiées }\end{array}$ \\
\hline \multicolumn{4}{|c|}{$(1500)$} \\
\hline \multirow[t]{3}{*}{ Insectivore } & Talpa sp. & $\mathrm{x}$ & 1 \\
\hline & Sorex sp. & $\mathrm{x}$ & \\
\hline & Sorex coronatus-araneus & & 1 \\
\hline \multirow[t]{12}{*}{ Rongeur } & Apodemus sylvaticus & $\mathrm{x}$ & 3 \\
\hline & Arvicola amphibius & $\mathrm{x}$ & \\
\hline & Arvicola terrestris & & 64 \\
\hline & Arvicola sapidus & & 04 \\
\hline & Castor fiber & $\mathrm{x}$ & 3 \\
\hline & Microtus agrestis & $\mathrm{x}$ & 22 \\
\hline & Microtus arvalis & $\mathrm{x}$ & 30 \\
\hline & Microtus agrestis/arvalis & & 11 \\
\hline & Microtus Terricola duode & cimcostatus & 2 \\
\hline & Microtus Terricola pyrenc & aicus & 2 \\
\hline & Microtus Terricola subter & raneus & 5 \\
\hline & Microtus Terricola sp. & & 1 \\
\hline \multirow[t]{2}{*}{ Petit carnivore } & Mustela nivalis & $\mathrm{x}$ & 2 \\
\hline & Mustela erminea & $\mathrm{x}$ & 1 \\
\hline \multirow[t]{2}{*}{ Batracien } & Rana sp. & $\mathrm{x}$ & $\mathrm{x}$ \\
\hline & Bufo sp. & $\mathrm{x}$ & $\mathrm{x}$ \\
\hline
\end{tabular}

\section{4 - With or without subdivisions: what are the differences?}

11 Let us now consider the example from Peyrazet (Lot, France). This site yielded a sequence dating from the Tardiglacial (Langlais et al. 2009). The protocol applied during the excavation enabled us to extract data relating to the location of small vertebrate remains by layer and by spit. Table 2 presents the counts of remains by layer for subsquare L6C, whereas figure 1 illustrates the evolution of the concentrations of each taxon in this same subsquare for each spit. Based on these spits, we observe that the small mammals are distributed unevenly throughout layer 4. Using statistical analysis based on a cluster analysis method and the Bray-Curtis dissimilarity coefficient, we observe a series of complexes (called B to F), that differ from the archaeostratigraphy. Layer 4 is characterized by the presence of four complexes, including two (B and E) which also incorporate spits from layers 3 and 5. Complex D of this layer stands out in particular by the presence of numerous insectivores, including water shrews (Neomys sp.) and crowned shrews (Sorex coronatus-araneus), as well as birch mice (Sicista betulina) and garden dormice (Eliomys quercinus). This association denotes a marshy environment, which disappears in the upper part of layer 4 (complex c). In addition, this analysis by spit allows us to question the reality of certain associations. For example, note in table 2 that layer 4 associates the snowy vole 
(Chionomys nivalis) with the water shrew (Neomys sp.), which are taxa from different environments. Nonetheless, an analysis by spit suggests that these taxa did not occur together. In this example, spits allow us to advance a biostratigraphy without the palimpsest effect induced by the archaeological layer.

The sequence from the site of Pradelles (Charente) (Maureille et al. 2010) is dated to the end of isotopic stage 4 and the beginning of stage 3. Two taxa predominate; the narrowheaded vole (Microtus gregalis) and the common vole (Microtus arvalis); representing about $85 \%$ of the determined individuals (Royer et al. 2013). Let us now only consider level 5, with large mammal remains accumulated mainly by large carnivores (Costamagno et al. 2008). This level 5 is perceived to be homogeneous from a lithostratigraphic and an archaeological point of view. Based on rodents, it is possible to interpret this level differently, either by taking account of the whole level or by dividing it into two sublevels (tab. 3).

If we consider the whole level, we observe that the number of individuals identified as common voles (M. arvalis) increases, whereas the presence of the narrow-headed vole (M. gregalis) is still predominant denoting a dry, steppic continental environment. Nonetheless, the proportions of these rodents are different if we subdivide level 5 into two sublevels (5-1 and 5-2). In sublevel 5-1, the presence of the narrow-headed vole is dominant in comparison to that of the common vole, whereas in sublevel 5-2, this ratio is inversed. Moreover, this second sublevel differs by the presence of the gray dwarf hamster (Cricetulus migratorius). Compared to those of sublevel 5-1, these results imply that sublevel 5-2 records a climatic amelioration.

Table 2 - Small vertebrate remains from Peyrazet (Lot) according to archaeological levels.

\begin{tabular}{|c|c|c|c|c|c|c|c|c|c|}
\hline & $\begin{array}{l}\text { Microtus } \\
\text { indet. }\end{array}$ & $\begin{array}{c}\text { Microtus } \\
\text { arvalis/agrestis }\end{array}$ & $\begin{array}{l}\text { Microtus } \\
\text { oeconomus }\end{array}$ & $\begin{array}{c}\text { Arvicola } \text { cf. } \\
\text { terrestris }\end{array}$ & $\begin{array}{c}\text { Chionomys } \\
\text { nivalis }\end{array}$ & $\begin{array}{l}\text { Apodemus } \\
\text { sylvaticus }\end{array}$ & $\begin{array}{l}\text { Eliomys } \\
\text { quercinus }\end{array}$ & $\begin{array}{c}\text { Sicista } \\
\text { betulina }\end{array}$ & $\begin{array}{l}\text { Myodes } \\
\text { glareolus }\end{array}$ \\
\hline & $\mathrm{N} \mathrm{ml} \inf$ & $\mathrm{N} \mathrm{ml} \mathrm{inf}$ & $\mathrm{N} \mathrm{ml} \inf$ & $\mathrm{N} \mathrm{m} 1 \mathrm{inf}$ & $\mathrm{N} \mathrm{m} 1 \inf$ & $\begin{array}{l}\text { Mand } \\
+\max \end{array}$ & $\begin{array}{l}\text { Mand } \\
+\max \end{array}$ & $\begin{array}{l}\text { Mand } \\
+\max \end{array}$ & NR \\
\hline Couche 1 & 0 & 0 & 0 & 0 & 0 & 0 & 0 & 0 & 0 \\
\hline Couche 2 & 1 & 2 & 0 & 1 & 0 & 0 & 0 & 0 & 0 \\
\hline Couche 3 & 4 & 202 & 3 & 3 & 0 & 16 & 0 & 0 & 1 \\
\hline Couche 4 & 23 & 586 & 223 & 38 & 1 & 10 & 1 & 2 & 0 \\
\hline \multirow[t]{3}{*}{ Couche 5} & 13 & 142 & 51 & 41 & 0 & 0 & 4 & 2 & 0 \\
\hline & $\begin{array}{c}\text { Sorex } \\
\text { coronatus- } \\
\text { araneus }\end{array}$ & $\begin{array}{c}\text { Sorex } \\
\text { minutus }\end{array}$ & $\begin{array}{l}\text { Crocidura } \\
\text { indet. }\end{array}$ & $\begin{array}{l}\text { Neomys } \\
\text { Indet. }\end{array}$ & & & & & \\
\hline & mand & mand & mand & mand & & & & & \\
\hline Couche 1 & 0 & 0 & 0 & 0 & & & & & \\
\hline Couche 2 & 0 & 0 & 0 & 0 & & & & & \\
\hline Couche 3 & 10 & 5 & 8 & 0 & & & & & \\
\hline Couche 4 & 64 & 22 & 0 & 9 & & & & & \\
\hline Couche 5 & 5 & 1 & 0 & 0 & & & & & \\
\hline
\end{tabular}

\section{5 - Contribution of subdivisions and application in the field}

14 The systematic use of subdivisions presents the advantage of spatially defining the origin of the micro-remains, independently of the archaeological and geological layers, 
and provides us with the possibility to reallocate objects recorded with Cartesian coordinates (fig. 2). This recording method also makes it possible to:

1. establish a detailed and independent biostratigraphy, which is not biased by litho- or archaeo-stratigraphic subdivisions (fig. 2) and which can be correlated with the latter, as shown by rare small vertebrate studies (Cochard 2004; Cuenca-Bescós et al. 2011; Pasty et al. 2012);

2. develop an approach comparing the distribution of non-coordinated objects (small vertebrate remains but also all the other micro remains, such as lithic remains and burnt bones), with coordinated pieces. An example of this was obtained from the study of the Tardiglacial site of Peyrazet (Lot), where the lack of correlation between the quantities of lithic material (accumulated by Man) and small mammals (accumulated by a non-human predator) was brought to light $(\mathrm{Rho}=0.10 ; \mathrm{p}=0.55)$. On the other hand, there is no correlation between the quantities of lithic material and fish ( $\mathrm{Rho}=0.10 ; \mathrm{p}=0.52)$ and a significant correlation between the quantities of small mammals and fish ( $R$ ho $=0.57 ; \mathrm{p}<$ 0.0001). These results thus suggest that a large part of the latter were also accumulated by non-human predators. From $-150 \mathrm{~cm}$ onwards, important quantities of small vertebrate remains are still present, whereas the density of lithic pieces is low, indicating that the cave was mainly occupied by non-human predators (fig. 3). This method thus offers the possibility to characterize site occupation phases, but also phases of human inoccupation of levels considered to be archaeologically sterile.

This approach was applied to the whole of the excavated site, and allowed for a spatial study of small vertebrate remains, which can then be compared with those of other remains. For example, the Magdalenian layer IIIa from Taillis-des-Coteaux (Vienne) (Primault et al. 2010) presents a similar distribution of rodent, bird and fish remains, localized in the cave entrance area. This distribution is different to the remains linked to anthropogenic activities, which are mainly spread out inside the cave and on the slope (Rambaud et al. 2011).

This differential distribution tends to imply that the fish, bird and rodent remains, result mainly from non-human predator accumulation;

3. produce impartial information allowing for an ulterior evaluation of the collection. This can also be compared to a reassessment of the other archaeological remains.

15 Nowadays, systematic sieving is often criticized as it is a fastidious and time-consuming operation. Nonetheless, it is essential for recovering archaeological remains that go unnoticed at the excavation, such as certain lithic or bone remains, indispensable for understanding human behaviour (e.g. Freeman et al. 1998; Soressi and Tavormina 2011; Val and Mallye 2011). It is important to underline that recording spits is more timeconsuming than layers, but it also provides more information. The recovery of small vertebrates in the field does not only depend on excavation methods, but also on the sieve mesh used by prehistorians. Meshes of 3 to $1.5 \mathrm{~mm}$ are generally used to retrieve the smallest lithic armatures, whereas small vertebrate specialists recommend meshes of 1.2 to $0.5 \mathrm{~mm}$, depending on fragmentation. The ideal method is clearly systematic sieving with meshes of $1.2 \mathrm{~mm}$ or less, as is the case at other sites, such as Atapuerca ( $0.5 \mathrm{~mm}$ mesh - pers. com. G. Cuenca-Bescós). When this method cannot be applied, two other strategies can be developed, depending on the site and excavation objectives. When the excavation is geared towards spatial analysis, it is appropriate to carry out systematic sieving, with a coarse mesh of 1.2 to $1.8 \mathrm{~mm}$, which is sufficient to assess the distribution of the density of remains. This approach should also include the finemeshed column sieving of samples in order to refine environmental reconstructions by incorporating the remains of the smallest species. When the excavation does not 
involve a spatial approach, such as refreshing a section, it is possible to column sieve samples with a fine mesh, with columns spread out along the section (for example a subsquare every metre). These two strategies present the advantage of being based on spit recording, within the site grid, and it is thereby possible to acquire adequate data for microfauna and to correlate them directly with the archaeological and geological data.

Figure 1 - Taxa counts according to spits and altitudes in subsquare L6C at Peyrazet (Lot). The variations of the three most frequent taxa (Microtus arvalis- agrestis, Microtus oeconomus and Arvicola cf terrestris) are represented as relative percentages. For the rest, each first lower molar and each mandible are represented by a circle to clearly illustrate their quantitative variations within the sequence.

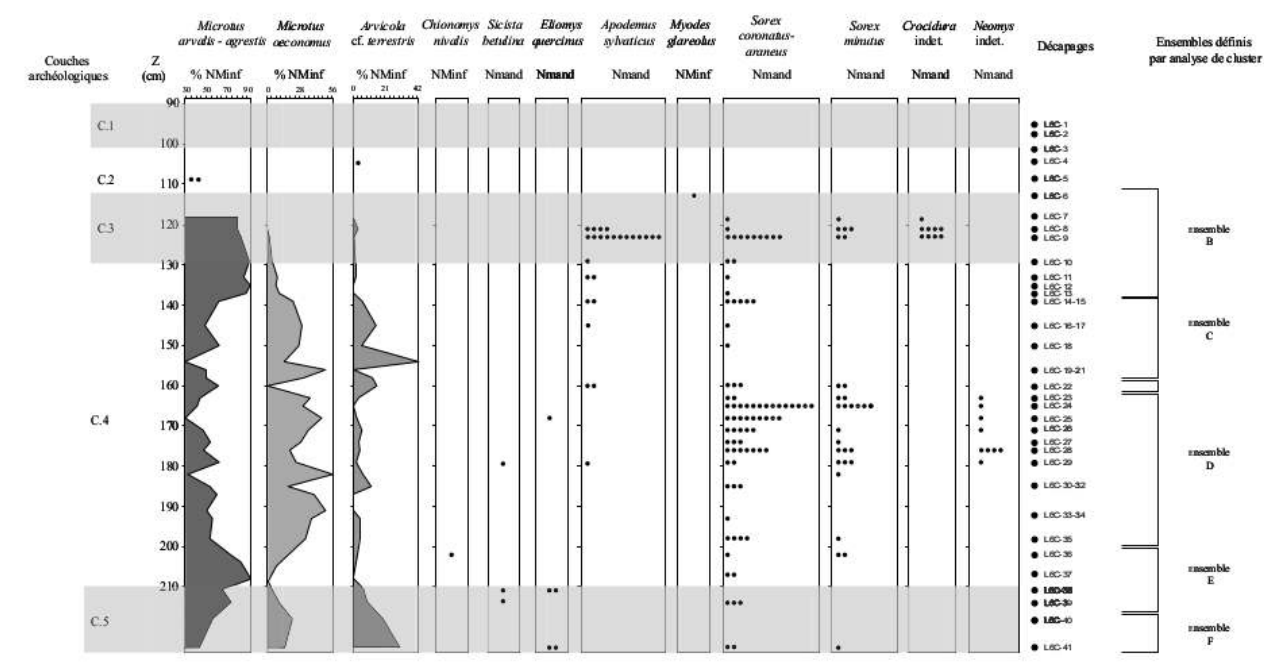

Table 3 - Minimal number of individuals for rodents at Les Pradelles (Charente). Level “ 5 total” corresponds to both sublevels 5-1 and 5-2.

\begin{tabular}{|c|c|c|c|c|c|c|c|c|c|}
\hline Espèces / Niveaux & $\begin{array}{c}\text { Niveau } \\
2 / 1 \\
\end{array}$ & $\begin{array}{c}\text { Niveau } \\
\mathbf{2 A} \\
\end{array}$ & $\begin{array}{c}\text { Niveau } \\
\text { 2B } \\
\end{array}$ & $\begin{array}{c}\text { Niveau } \\
4 \mathrm{~A} \\
\end{array}$ & $\begin{array}{c}\text { Niveau } \\
4 \mathrm{~B} \\
\end{array}$ & $\begin{array}{c}\text { Niveau } \\
5-1 \\
\end{array}$ & $\begin{array}{c}\text { Niveau } \\
5-2 \\
\end{array}$ & $\begin{array}{l}\text { Niveau } \\
5 \text { total } \\
\end{array}$ & $\begin{array}{c}\text { Total } \\
(\mathrm{NMI}=1250)\end{array}$ \\
\hline Apodemus sylvaticus & 0 & 0 & 0 & 1 & 1 & 0 & 1 & 1 & 3 \\
\hline Arvicola terrestris & 1 & 4 & 1 & 1 & 2 & 2 & 5 & 7 & 17 \\
\hline Cricetelus migratorius & 0 & 0 & 0 & 1 & 0 & 0 & 4 & 4 & 5 \\
\hline Dicrostonyx torquatus & 0 & 1 & 1 & 4 & 64 & 26 & 18 & 44 & 142 \\
\hline Eliomys quercinus & 0 & 0 & 0 & 0 & 0 & 1 & 0 & 1 & 1 \\
\hline Glis glis & 0 & 0 & 0 & 0 & 1 & 0 & 0 & 0 & 1 \\
\hline Marmota marmota & 0 & 0 & 0 & 1 & 2 & 0 & 0 & 0 & 4 \\
\hline $\begin{array}{c}\text { Microtus arvalis } \\
\text { Microtus }\end{array}$ & 4 & 13 & 3 & 14 & 39 & 31 & 147 & 178 & 272 \\
\hline arvalis/agrestis & 0 & 0 & 0 & 0 & 3 & 1 & 3 & 4 & 8 \\
\hline Microtus gregalis & 7 & 35 & 8 & 26 & 296 & 168 & 120 & 288 & 782 \\
\hline Microtus oeconomus & 0 & 0 & 1 & 2 & 3 & 1 & 7 & 8 & 15 \\
\hline
\end{tabular}


Figure 2 - Theoretical illustration presenting the difference between a biostratigraphy based on archaeostratigraphic levels from the square K7A (Schema $A$ ) and a biostratigraphy obtained using successive spits (Dec) from the square $K 7 \mathrm{~A}$, which are independent of the archaeostratigraphy (Schema B).

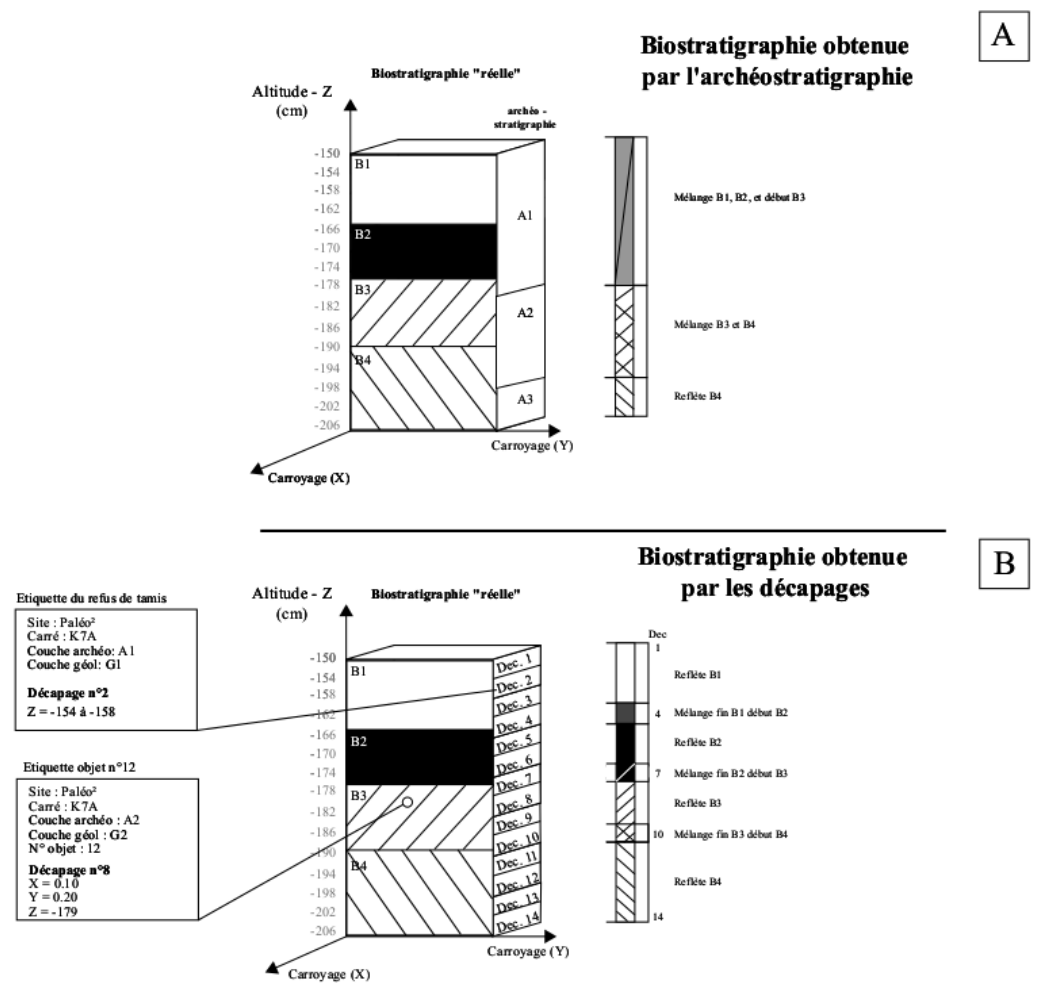


Figure 3 - Quantitative variations in rodent, fish and lithic remains per litre of sediment (expressed in logarithm) obtained by spits from the subsquare L6C of Peyrazet (Lot) according to altitude. NR: Number of remains; L: Litre of sediments; Z: altitude in centimetres. The grey and non-grey fluctuations illustrate the archaeological levels

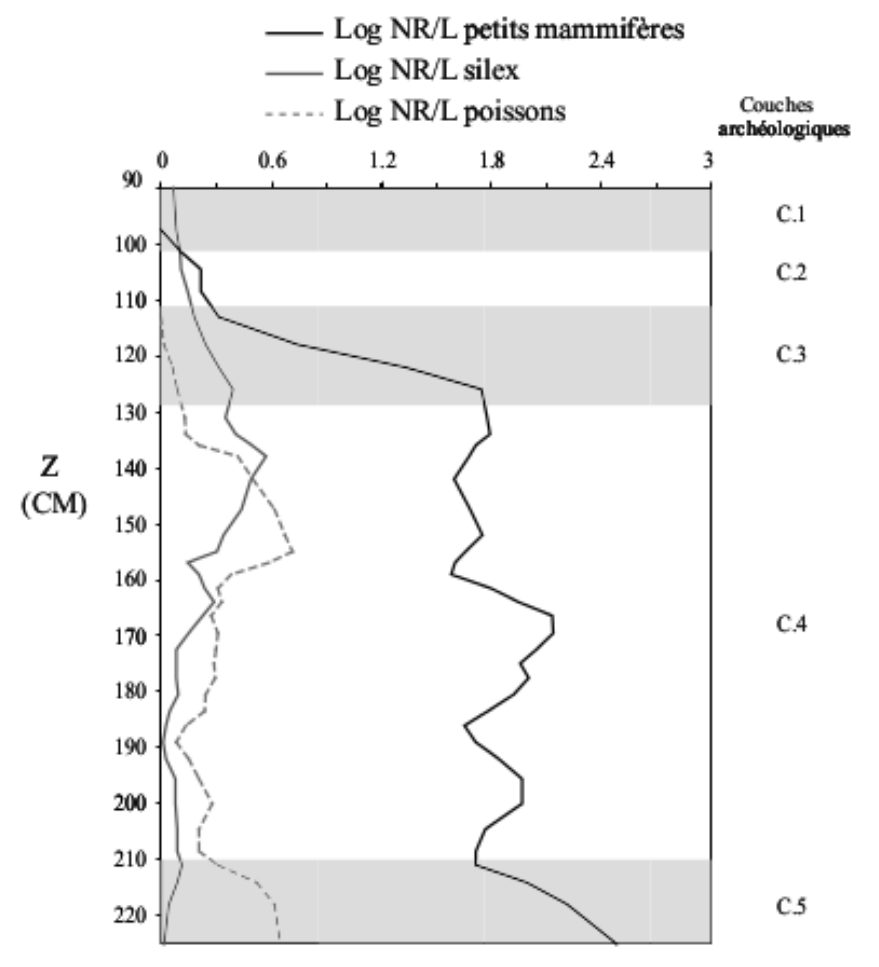

\section{6 - Conclusion}

Small vertebrate remains bear important environmental, archaeozoological and taphonomic information. However, their potential to provide information depends on the excavation methods applied to the site. Due to their small size, small vertebrate remains are very rarely recorded with a system of Cartesian coordinates in archaeological sites, as most of them are collected from sieve residues. This article underlines the necessity to acquire impartial spatial information from a spatially referenced hexahedral area in the site. These data are independent of the archaeological and geological layers, and thus allow for the study of the spatial distribution of small vertebrate remains, the proposition of biostratigraphies based on these remains and the recording of information necessary for comparisons with the other archaeological remains and a possible ulterior reevaluation of the collection. 


\section{BIBLIOGRAPHY}

ANDREWS P. 1990 - Owls, caves, and fossils: predation, preservation, and accumulation of small mammal bones in caves, with an analysis of the Pleistocene cave faunas from Westbury-sub-Mendip, Somerset, UK. University of Chicago Press, $231 \mathrm{p}$.

AUFFRAY J.C., RENAUD S. et CLAUDE J. 2009 - Rodent biodiversity in changing environments. Kasetsart Journal, Natural Sciences, 43, 83-93.

BORDES F. et BOURGON M. 1951 - Le gisement du Pech de l'Azé Nord. Campagnes 1950-1951. Les couches inférieures à Rhinoceros Mercki. Bulletin de la Société préhistorique de France, p. 520-538.

BORDES F., RIGAUD J.-P. et SONNEVILLE-BORDES (de) D. 1972 - Des buts, problèmes et limites de l'archéologie paléolithique. Quaternaria, 16, p. 15-34.

BOUCHUD J. 1952 - Étude des rongeurs et des oiseaux de l'abri Castanet. Bulletin de la Société préhistorique de France, 49, p. 267-271.

CHALINE J. 1972 - Les rongeurs du Pléistocène moyen et supérieur de France. Cahiers de Paléontologie. CNRS, Paris, $400 \mathrm{p}$.

CHALINE J. 1977 - Les rongeurs au pilori ? Analyse critique des reconstitutions paléoécologiques en microthériodontologie. In : LAVILLE H. et RENAULT-MISKOVSKY J. (eds.), Approche écologique de l'Homme fossile. Paris, p. 77-81.

COCHARD D. 2004 - Étude préliminaire des micromammifères des niveaux Paléolithique moyen de Chez Pinaud à Jonzac (Charente, France). In: AIRVAUX J. (ed.) Le site Paléolithique de Chez-Pinaud à Jonzac, Charente-Maritime. Préhistoire du Sud-Ouest, p. 157-162.

COSTAMAGNO S., BEAUVAL C., LANGE-BADRÉ B., VANDERMEERSCH B., MANN A. et MAUREILLE B. 2008 - Homme ou carnivores ? Protocole d'étude d'ensembles osseux mixtes : l'exemple du gisement moustérien des Pradelles (Marillac-le-Franc, Charente). P@lethnologie, 1, p. 372-400.

CUENCA-BESCÓS G., STRAUS L.G., GONZÁLEZ MORALES M.R. et GARCÍA PIMIENTA J.C. 2009 - The reconstruction of past environments through small mammals: from the Mousterian to the Bronze Age in El Mirón Cave (Cantabria, Spain). Journal of Archaeological Science, 36, 4, p. 947-955.

CUENCA-BESCÓS G., MELERO-RUBIO M., ROFES J., MARTÍNEZ I., ARSUAGA J.L., BLAIN H.A., LÓPEZGARCÍA J.M., CARBONELL E. et BERMUDEZ DE CASTRO J.M. 2011 - The Early-Middle Pleistocene environmental and climatic change and the human expansion in Western Europe: A case study with small vertebrates (Gran Dolina, Atapuerca, Spain). Journal of Human Evolution, 60, 4, p. 481-491.

FREEMAN L.G., GONZALEZ ECHEGARAY J., POKINES J.T., STETTLER H.K. et KRUPA M. 1998 Tamisage ultra fin et récupération de l'outillage : observations réalisées à El Juyo (Espagne cantabrique). L'Anthropologie, 102, 1, p. 35-44.

HARLÉ E. 1906 - Lemming à collier (Myodes torquatus P.) de Teyjat (Dordogne). Bulletin de la Société Géologique de France, 6, p. 11.

HEDBERG H.D. 1979 - Guide stratigraphique international. Classification, terminologie et règles de procédure. Paris, $233 \mathrm{p}$.

HERNÁNDEZ FERNÁNDEZ M. 2006 - Rodent paleofaunas as indicators of climatic change in Europe during the last 125,000 years. Quaternary Research, 65, 2, p. 308-323. 
JEANNET M. 1978 - Recherches sur les rongeurs quaternaires en 1978. Nouvelles Archives du Museum d'Histoire naturelle de Lyon, 16, suppl., p. 71-74.

JEANNET M. 2010 - L'écologie quantifiée. Essai de description de l'environnement continental à l'aide des microvertébrés. Préhistoires Méditerranéennes, 1, p. 11-34.

LANGLAIS M., LAROULANDIE V., AVEC LA COLLABORATION DE, BRUXELLES L., CHALARD P., COCHARD D., COSTAMAGNO S., DELFOUR G., KUNTZ D., LE GALL O., PÉTILLON J.-M. et QUEFFELEC A. 2009 - Les fouilles de la grotte-abri de Peyrazet (Creysse, Lot) : nouvelles données pour le Tardiglaciaire quercinois. Bulletin de la Société préhistorique française, 106, 1, p. 150-152.

LAPLACE-JAURETCHE G. 1971 - De l'application des coordonnées cartésiennes à la fouille stratigraphique. Munibe, 23, 2-3, p. 223-236.

LAPLACE-JAURETCHE G. et MÉROC L. 1954 - Application des coordonnées cartésiennes à la fouille d'un gisement. Bulletin de la Société préhistorique de France, 51, 1-2, p. 58-66.

LEROI-GOURHAN A. 1950 - La grotte du Loup, Arcy-sur-Cure (Yonne). Bulletin de la Société préhistorique de France, 47, 5, p. 268-280.

LEROI-GOURHAN A. 1988 - Dictionnaire de la Préhistoire. Presses universitaires de France.

LE LOUARN H. et QUÉRÉ J.P. 2003 - Les rongeurs de France : faunistique et biologie. Editions Quae, 260 p.

LÓPEZ-GARCÍA J.M., BLAIN H.A., CUENCA-BESCÓS G., RUIZ-ZAPATA M.B., DORADO-VALI-O M., GIL-GARCÍA M.J., VALDEOLMILLOS A., ORTEGA A.I., CARRETERO J.M., ARSUAGA J.L., BERMÚDEZ DE CASTRO J.M. et CARBONELL E. 2010 - Palaeoenvironmental and palaeoclimatic reconstruction of the latest Pleistocene of El Portalón site, Sierra de Atapuerca, northwestern Spain. Palaeogeography, Palaeoclimatology, Palaeoecology, 292, 3, p. 453-464.

LUMLEY (de) H. 1969 - Les Méthodes de fouilles préhistoriques. Mémoires de la Société Préhistorique Française, 7, p. 13-15.

LUMLEY (de) H. 1972 - Méthodes de fouilles et d'études d'un gisement préhistorique. Etudes Quaternaires, 1, p. 7-17.

MARQUET J.-C. 1993 - Paléoenvironnement et chronologie des sites du domaine Atlantique français d'âge Pléistocène moyen et supérieur d'après l'étude des rongeurs. Tours: Les Cahiers de la Claise, Supplément 2, $330 \mathrm{p}$.

MAUREILLE B., MANN A., BEAUVAL C., BORDES J.G., BOURGUIGNON L., COSTAMAGNO S., COUCHOUD I., FAUQUIGNON J., GARRALDA BENAJES M.D., GEIGL E.M., GRÜN R., GUIBERT P., LACRAMPE F., LAROULANDIE V., MARQUET J.C., MEIGNEN L., MUSSINI C., RENDU W., ROYER A., SEGUIN G. et TEXIER J.-P. 2010 - Les Pradelles à Marillac-le-Franc (Charente). Fouilles 2001-2007 : nouveaux résultats et synthèse. In: BUISSON-CATIL J. et PRIMAULT J. (eds.), Préhistoire entre Vienne et Charente. Hommes et sociétés du Paléolithique. Chauvigny: Association des Publications Chauvinoises, p. 145-162.

MAYHEW D.F. 1977 - Avian predators as accumulators of fossil mammal material. Boreas, 6, p. 25-31.

PASSEMARD E. 1936 - Le moustérien à l'Abri Olha en pays basque. Société d'Impressions Typographiques. $46 \mathrm{p}$.

PASTY J.-F., COSTAMAGNO S., MISTROT V., LAROULANDIE V., ALIX P., BALLUT C., PASTY-VANDE WALLE H. et MURAT R. 2012 - Implications biostratigraphiques et paléoenvironnementales des 
occupations du Paléolithique moyen et du Châtelperronien du site de La Tour Fondue à Chauriat (Puy-de-Dôme, France). Paleo, 23, p. 189-222.

PRIMAULT J., BERTHET A.-L., BROU L., DELFOUR G., GABILLEAU J., GRIGGO C., GUÉRIN S., GAMBIER D., HOUMARD C., JEANNET M., LACRAMPE F., LANGLAIS M., LAROULANDIE V., LIARD M., LIOLIOS D., LOMPRÉ A., LUCQUIN A., MISTROT V., RAMBAUD D., SCHMITT A., SOLER L., TABORIN Y. et VISSAC C. 2010 - La grotte du Taillis-des-Coteaux à Antigny (Vienne). In : BUISSONCATIL J. et PRIMAULT J. (eds.), Préhistoire entre Vienne et Charente. Hommes et sociétés du Paléolithique. Chauvigny: Association des Publications Chauvinoises, p. 271-293.

RAMBAUD D., LAROULANDIE V., PRIMAULT J. et BEAREZ P. 2011 - Les poissons et les oiseaux du Taillis des Coteaux (Antigny, Vienne), niveaux magdaléniens : origine naturelle ou culturelle? In : LAROULANDIE V., MALLYE J.-B. et DENYS C. (eds.), Taphonomie des petits vertébrés: référentiels et transferts aux fossiles. Actes de la Table Ronde du RTP Taphonomie, Talence 20-21 october 2009. Oxford: BAR International Series, p. 167-179.

REINECK H.-E. et SINGH I.B. 1975 - Depositional sedimentary environments: with reference to Terrigenous clastics. Berlin: Springer-Verlag, $439 \mathrm{p}$.

ROYER A., LÉCUYER C., MONTUIRE S., ESCARGUEL G., FOUREL F., MANN A. et MAUREILLE B. 2013 - Late Pleistocene (MIS 3-4) climate inferred from micromammal communities and $\delta \mathrm{d} 180$ of rodents from Les Pradelles, France. Quaternary Research, 80, p. 113-124.

SIMARD S. 1966 - Etude paléontologique des micromammiferes de la grotte du Regourdou (Montignac, Dordogne). Faculté des Sciences de l'Université de Paris, 1966. 118 p.

SONNEVILLE-BORDES (de) D. et MORTUREUX B. 1955 - L'abri Caminade, commune de La Canéda (Dordogne). Bulletin de la Societé préhistorique de France, 52, p. 609-619.

SORESSI M. et TAVORMINA C. 2011 - L'intérêt du tri du refus de tamis de maille $5 \mathrm{~mm}$ et $2 \mathrm{~mm}$ dans l'analyse d'assemblages lithiques du Protoaurignacien et de l'Aurignacien ancien. Bulletin de liaison et d'information - Association des archéologues; Direction des antiquités Poitou-Charentes 40, p. 9-16.

STAHL P.W. 1996 - The recovery and interpretation of microvertebrate bone assemblages from archaeological contexts. Journal of Archaeological Method and Theory, 3, 1, p. 31-75.

VAL A. et MALLYE J.-B. 2011 - Taphonomie du fouilleur : influence de la maille de tamis sur la représentation anatomique des petits animaux à fourrure. In : DENYS C.,

LAROULANDIE V. et MALLYE J.-B. (eds.), Taphonomie des Petits Vertébrés: Référentiels et Transferts aux Fossiles. BAR International Series, p. 93-100.

VAUFREY R. 1956 - Fouilles et « Archéologie sur le terrain ». Bulletin de la Société préhistorique de France, p. 491-503.

VILLA P. 2004 - Taphonomy and stratigraphy in European prehistory. Before farming, 1, p. 1-20.

\section{ABSTRACTS}

The remains of small vertebrates are generally recorded and analyzed according to archaeological levels defined during excavations. As a consequence, the study of such assemblages is influenced by these predefined levels, creating possible analytical biases and errors in the characterization of biostratigraphical units. The study of small vertebrate assemblages from Olha 1 (Pyrénées-Atlantiques), Les Pradelles (Charente) and Peyrazet (Lot) demonstrates the benefit of systematically recording detailed spatial information for these types 
of remains. Independent subdivisions (spits) defined by Cartesian coordinates allow independently defined biostratigraphical units to be correlated with litho- and archaeostratigraphy.

Les restes de petits vertébrés de nombreuses collections sont conditionnés et étudiés selon les couches archéologiques caractérisées lors de la fouille. De facto, l'analyse de ces collections est influencée par ces ensembles prédéfinis, ce qui biaise d'éventuelles réévaluations et de nouveaux découpages biostratigraphiques. S'appuyant sur l'analyse de trois collections de petits vertébrés issues de gisements fouillés à différentes périodes (les sites d'Olha I dans les PyrénéesAtlantiques, des Pradelles en Charente et de Peyrazet dans le Lot), ce travail met en évidence l'avantage d'enregistrer précisément la provenance spatiale de ce type de microvestiges. Cet article propose donc que les restes de petits vertébrés soient systématiquement enregistrés et collectés par décapages successifs (ou passes) dont la situation spatiale est définie non pas par rapport à une couche archéologique, mais par des coordonnées cartésiennes. Ce mode d'enregistrement permet d'établir des biostratigraphies réellement indépendantes des autres stratigraphies (i.e. litho-, archéo-, chronostratigraphies) et corrélables à ces dernières.

INDEX

Mots-clés: biostratigraphie, petits vertébrés, mode d'enregistrement des données, décapages

Keywords: biostratigraphy, small vertebrates, recording methods, spits

\section{AUTHOR}

\section{AURÉLIEN ROYER}

PACEA, UMR CNRS 5199, Université de Bordeaux, Allée Geoffroy Saint-Hilaire, FR-33615 Pessac aurelien_royer@hotmail.com 